\title{
A. IDENTITAS JURNAL
}

- Nama jurnal : Jurnal Teologi Injili dan Pembinaan Warga Jemaat

- Volume : 4

- Nomor : 1

- Halaman : :103-112

- Tahun terbit : 2020

- Judul jurnal : PENCIPTAAN “RUANG KEEMPAT” SEBAGAI BASIS PEMBINAAN WARGA GEREJA PRIBUMI DALAM MENGGEREJA DI JAWA

- Nama penulis : Akris Mujiyono \& Febri Jati Nugroho

\section{B. ISI JURNAL}

- MASALAH PENELITIAN

Gereja yang benar seharunya menjalankan tugasnya sebagai pembawa damai, hal ini bisa dilakukan jika gereja menjadi bagian dari konteks. Namun jika gereja diasingkan oleh konteks artinya ada maslah yang harus diselesaikan di dalam gereja itu. Gereja Kristen Jawa Tengah Utara (GKJTU), dengan gereja lain di Jawa mengalami keterasingan dari konteks, hal ini terjadi karena ada persoalan identitas Hybrid gereja.

- LOKASI PENELITIAN

GKJTU (Gereja Kristen Jawa Tengah Utara)

- METODE PENELITIAN

Pengumpulan data menggunakan metode penelitian pustaka atau studi pustaka serta dokumen gerejawai yang berkaitan dengan pokok penelitian dan metode wawancara. Data yang telah dikumpulkan akan dianalisis secara mendalam menggunakan metode penelitian kualitatif.

- TEORI YANG DIGUNAKAN

Penulis menggunakan teori poskolonial Homi K. Bhabha perihal pembentukan ruang keempat. 


\section{- HASIL PENELITIAN}

Saat perintisan GKJTU, terdapat tiga tingkatan status sosial. Tingkat pertama adalah Bangsa Eropa (Belanda), yang merupakan tertinggi. Kedua adalah kelas asing asia, yaitu orang Cina dan Arab, kebanyakan mereka adalah para pengusaha dan pedagang yang memiliki modal. Sedang kelas ketiga, yang paling rendah dan miskin, adalah kelas pribumi. Dalam konteks ini bangsa pribumi ingin menaikkan status sosial mereka ingin mendekati budaya Belanda, upaya ini terjadi pada orang-orang Kristen Jawa. Orang-orang Jawa menaikan kelas sosialnya dengan beragama Kristen, yang merupakan agama penjajah Belanda. Dengan demikian budaya dari orang Kristen Jawa dengan orang Jawa yang tidak menjadi Kristen berbeda, tapi tidak benar-benar sama juga dengan Belanda. Orang Kristen Jawa ini seolah poisinya ditengah, tidak di budaya Jawa lagi dan tidak sama dengan Belanda, akhirnya Gereja melakukan hibriditas kembali dengan budaya Jawa (membentuk ruang keempat). Adapun beberapa bidang yang harus dilakukan hibriditas : Hibriditas Corak Teologi, Hibriditas Dogma, dan Hibriditas Ritual.

\section{- KEKURANGAN DAN KELEBIHAN}

Kelebihan juranal ini bahasa yang digunakan mudah dimengerti untuk orang awam sekalipun, penjelasana yang disajikan tidak bertele-tele, pengumpulan data yang lengkap sehingga tidak timbulnya ketidakjelasan makna.

Adapun kekurangan dari jurnal ini pembahasan mengenai teologiah yang begitu banyak sehingga tidak semua orang tertarik dengan pembahasan juranl walaupun sudah dikaji secara lemgkap dan menggunakan bahasa yang sederhana. 